Theory and Building Practice

Vol. 3, No. 2, 2021

https://doi.org/10.23939/jtbp2021.02.052

Uliana Marushchak, Myroslav Sanytsky, Nazar Sydor, Ihor Margal

\title{
DESIGNING OF ALKALINE ACTIVATED CEMENTING MATRIX OF ENGINEERED CEMENTITIOUS COMPOSITES
}

\author{
Department of Building Production, \\ Lviv Polytechnic National University \\ nazar.sydor@ukr.net
}

(C) Marushchak U., Sanytsky M., Sydor N., Margal I., 2021

The development of high-performance materials, which are characterized by high compressive and flexural strength, durability and performance properties, is an urgent problem of modern construction. Engineered cementitious composites are one such material. Improving of properties of composites is achieved by partial replacement of cement with supplementary cementitious materials. The ratio of binder and filler components and superplasticizer consumption were selected. The optimal ratio of cement:fly ash:sand is 1:1:1 and the dosage of polycarboxylate superplasticizer is $0.75 \%$ by weight of the binder. The reduction of the negative impact of the increased amount of fly ash, which is characterized by low reactivity, is provided by the introduction of metakaolin and alkaline hardening activator. Alkaline activated cement system is characterized by increasing of the early strength in 1.5 times comparison with equivalent mixture without alkaline activator. Strength of alkaline activated cementing matrix after 28 days is $66.1 \mathrm{MPa}$ and specific strength $\mathrm{Rc} 2 / \mathrm{Rc28}$ is 0.61 .

Keywords: engineered cementitious composite, alkaline activation, fly ash, metakaolin, policarboxylate superplasticizer, strength

\section{Introduction}

Such qualities of concrete as versatility, durability, availability of raw materials have made it the most popular building material in the world. It has undergone major changes since its inception to the present day. Scientific and technological progress in the construction industry has prompted the creation of new generation structures and buildings. This has led to the need to increase the physical and mechanical properties of concrete, in particular its compressive strength (Sanytsky, 2020; Torres, 2016). However, high-strength concrete is a brittle material in which deformations are localized at the site of formation of the first crack after the ultimate loads. The formation of cracks reduces the bearing capacity and corrosion resistance of concrete and reinforced concrete structures, which can lead to a deterioration in the durability of structures during their operation.

The problem of cracking in high-strength concrete is solved by modifying with fiber. Engineered cementitious composites (ECCs) are a special type of highly functional fiber-reinforced cementing composites ( $\mathrm{Li}, 2003)$. The use of fibers contributes to the increase in flexural strength, which is due to the provision of fiber bearing capacity due to the interphase connection with the matrix after its destruction (Marcalikova, 2020). The use of fibers reduces the brittleness characteristic of cement paste due to the perception of tensile forces, and also prevents the displacement of the blocks of the matrix under load (Gholizadeh, 2018).

Engineered cementitious composites show certain load-bearing capacity that exceeds the peak load and are characterized by less fragility and higher fracture energy than conventional concrete, which is important under dynamic loads. The complex load may even increase and exceed the strength of the formation of the first crack in the case of multiple cracking (Chethan, 2015). In this case, the bearing 
capacity of the ECC does not change after the appearance of the first crack, which leads to deformation hardening, which is accompanied by multiple cracking.

In order to achieve high tensile ductility and a small opening width of crack while maintaining a low fiber content, the composite must be optimized by use of micromechanical methods. The micromechanic theory involves the optimization of the component composition and microstructure of the material taking into account the interaction of the cement matrix and fibers, which provides crosslinking of the structure (Chethan, 2015; Li, 2003; Yu, 2018). The concept of high strength ECC base on principle of tightly packed matrix to increase the flexural and compressive strength of the material, the fiber in turn counteracts the high fragility of the matrix. The dense matrix gives high adhesion to the fiber, which provides high strength of the material after cracking (Mangulkar, 2013). Coarse aggregate is not used in engineered cementitious composites, as well as a limited amount of fine aggregate to control this process (Chethan, 2015), as they lead to an increase in the width of the cracks.

However, the increased consumption of cement in the ECC compared to concrete can lead to increased cracking, which is due to increased heat and shrinkage (Zhang, 2009). Reduction of heat evolution and shrinkage is provided by partial replacement of cement with additional cementing materials, in particular ash, ash, chalk, zeolite (Sanytsky, 2020; Sobol, 2014; Borziak, 2019). However, the introduction of fly ash due to low reactivity leads to a decrease in strength in both early and late hardening, which leads to the use of ultrafine active mineral additives with increased pozzolanic activity, in particular microsilica, metakaolin (Marushchak, 2018).

One of the effective methods of hardening accelerating of the strength of binders with high content mineral additives is alkaline activation, due to the introduction of alkali metal salts (Krivenko, 2018). This will facilitate the acceleration of clinker minerals hydration and pozzolanic reactions in the system of mineral additives, packing intergranular space, improving the transition zone between the cement matrix and the aggregate.

Highly effective polycarboxylate superplasticizers are used to control the rheological properties of ECC mixtures, which allows to reduce porosity and increase the strength of composites (Plank, 2015; Tolmachov, 2017).

Therefore, development of cement system modified with alkaline-sulfate activator PCE complex additive and study of the processes of their structure formation are promising

\section{Aim of this article}

The aim of this study is to optimize the composition of alkaline-activated cementing matrix for engineered cementitious composites according to strength criteria.

\section{Materials and experimental methods}

The Portland cement CEM I 42.5R JSC "Ivano-Frankivskcement" according to EN 196-1, low calcium fly ash from Burshtyn thermal power plant and metakaolin were used to prepare binder matrix of Engineered Cementitious Composites. Natural quartz sand $\left(\mathrm{M}_{\mathrm{F}}=1.24\right)$ was used as fine aggregate. The Glenium ACE430 based on polycarboxylate ether polymers was used for regulation of rheological properties of composites. The sodium sulfate $\mathrm{Na}_{2} \mathrm{SO}_{4}$ as alkaline activator of cementing matrix was used in the investigations. The Blaine specific surface areas of CEM I 42.5R, fly ash, and metakaolin were 345,420 and $1300 \mathrm{~m}^{2} / \mathrm{kg}$ respectively. Experimental and statistical modeling of the matrix of ECC was performed by the method of orthogonal-central compositional planning.

Components of matrix of the ECC were mixed according to EN 196-1 procedure. Superplasticizer and sodium sulfate was added with mixture water. The consistency of the ECC mixture was determined using the flow table test according to EN 1015-3. The flowing of compositions variate from 170 to $180 \mathrm{~mm}$. The samples $20 \mathrm{~mm} \times 20 \mathrm{~mm} \times 80 \mathrm{~mm}$ were unformed after $24 \mathrm{~h}$ and cured in normal condition (90-100\% RH at $20 \pm 2{ }^{\circ} \mathrm{C}$ ). The samples was tested on compressive, flexural strength after 2 and 28 days. 


\section{Results and discussions}

The micromechanics model involves achieving the packing effect and use of fly ash to reduce the consumption of binder. It was shown that the optimal binder-sand ratio for Engineered Cementitious Composites is 2:1 (Sydor, 2021). The using of fly ash which has low activity leads to decreasing of compressive strength in both early and late hardening time. The main factor of strength increasing of Portland cement systems is reducing of water consumption while ensuring the necessary flowability due to using of superplasticizers. Investigation of the influence of these factors on the strength indicators was carried out according to two-factor three-level experiment. The amount of fly ash as the ratio of cement:fly ash $\left(\mathrm{X}_{1}=0 ; 1 ; 2\right)$ and amount of polycarboxylate superplasticizer PCE $\left(\mathrm{X}_{2}=0 ; 0.75 ; 1.50 \mathrm{wt} . \%\right)$ were chosen as variable factors. The flowability of the mixture was stabilized at 170-180 mm when changing the prescription levels of selected factors.

As a result of processing of experimental data, regression equations for water-binder ratio ( $\mathrm{Yw} / \mathrm{c})$, compressive strength after 2 and 28 days $\left(\mathrm{YR}_{\mathrm{c} 2}, \mathrm{YR}_{\mathrm{c} 28}\right)$ and flexural strength after 2 and 28 days $\left(\mathrm{YR}_{\mathrm{fl} 2}\right.$, $\mathrm{YR}_{\mathrm{f} 128}$ ) were obtained by the method of least squares that adequately describe dependence of indicators as system optimization criteria on variable factors.

$$
\begin{gathered}
\mathrm{Y}_{\mathrm{W} / \mathrm{C}}=0.22+0.06 \mathrm{X}_{2}+0.01 \mathrm{X}_{1}^{2}+0.02 \mathrm{X}_{2}^{2} \\
\mathrm{YR}_{\mathrm{c} 2}=28.5-1.93 \mathrm{X}_{1}+6.63 \mathrm{X}_{2}-3.13 \mathrm{X}_{1}^{2}-5.73 \mathrm{X}_{2}^{2}+0.6 \mathrm{X}_{1} \mathrm{X}_{2} \\
\mathrm{YR}_{\mathrm{c} 28}=56.9-6.08 \mathrm{X}_{1}+2.7 \mathrm{X}_{2}-1.18 \mathrm{X}_{1}^{2}-5.08 \mathrm{X}_{2}^{2}+2.1 \mathrm{X}_{1} \mathrm{X}_{2} \\
\mathrm{YR}_{\mathrm{fl} 2}=3.16-0.68 \mathrm{X}_{1}+0.35 \mathrm{X}_{2}-0.28 \mathrm{X}_{1}^{2}-0.08 \mathrm{X}_{2}^{2}+0.18 \mathrm{X}_{1} \mathrm{X}_{2} \\
\mathrm{YR}_{\mathrm{fl} 28}=6.16-1.43 \mathrm{X}_{1}+0.80 \mathrm{X}_{2}-0.23 \mathrm{X}_{1}^{2}-0.13 \mathrm{X}_{2}^{2}+0.13 \mathrm{X}_{1} \mathrm{X}_{2}
\end{gathered}
$$

Isoparametric surfaces and diagrams are constructed according to the obtained regression equations (Fig. 1, 2).

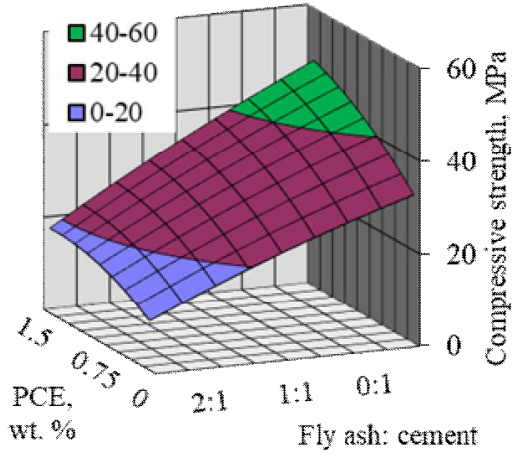

$a$

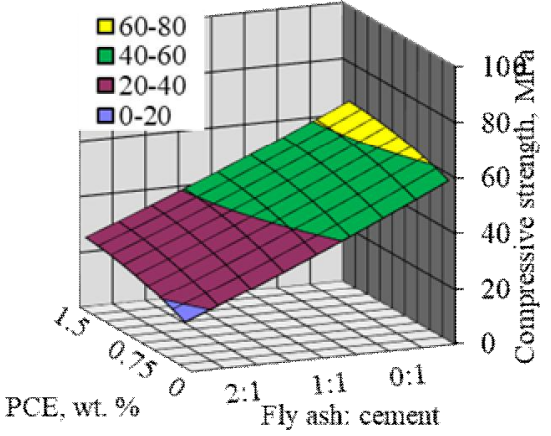

$b$

Fig. 1. Response surfaces of compressive strength of cementing matrix after $2(a)$ and $28(b)$ days

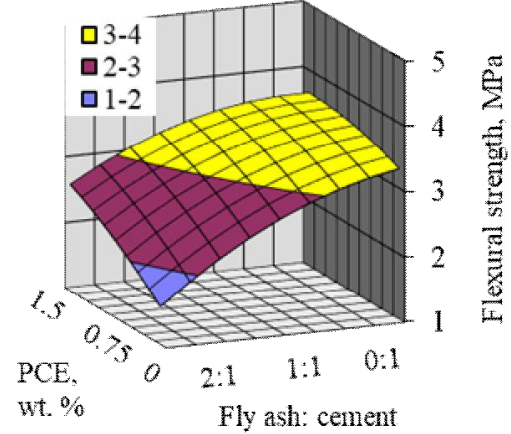

$a$

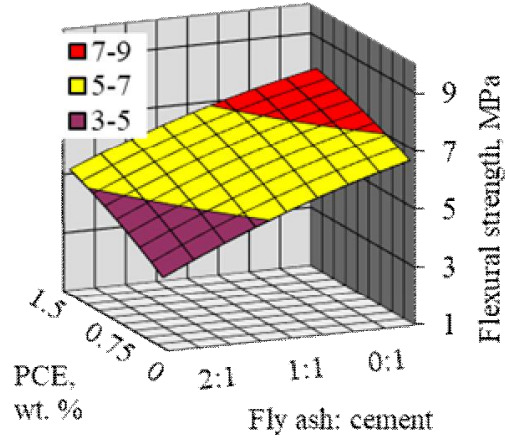

$b$

Fig. 2. Response surfaces of flexural strength of cementing matrix after $2(a)$ and $28(b)$ days 
Analysis of the obtained polynomial regression equations and experimental statistical models of concrete showed that with increasing of amount of fly ash in the ratio of cement: fly ash to 1:2 causes decreasing of compressive strength after 2 days (from 32.2 to $11.6 \mathrm{MPa}$ ) and flexural strength (from 3.3 to $1.5 \mathrm{MPa}$ ). With the introduction of $0.75-1.5 \mathrm{wt}$. \% PCE, due to the significant water-reducing effect (by 24-38\%), the strength of the modified concrete increases by 1.2-1.5 times and reaches values of 42.7 and 48.3 MPa. As can be seen from Fig. 3, $a$, flexural strength of composites decreases gradually at ratio fly ash:cement from 0:1 to 1:1 and sharply from 1:1 to 2:1. Modified composite with cement:fly ash:sand ratio 1:1:1 and PCE 0.75 wt. \% characterizes compressive strength after 28 days of $56.0 \mathrm{MPa}$ and flexural strength of $6.1 \mathrm{MPa}$.
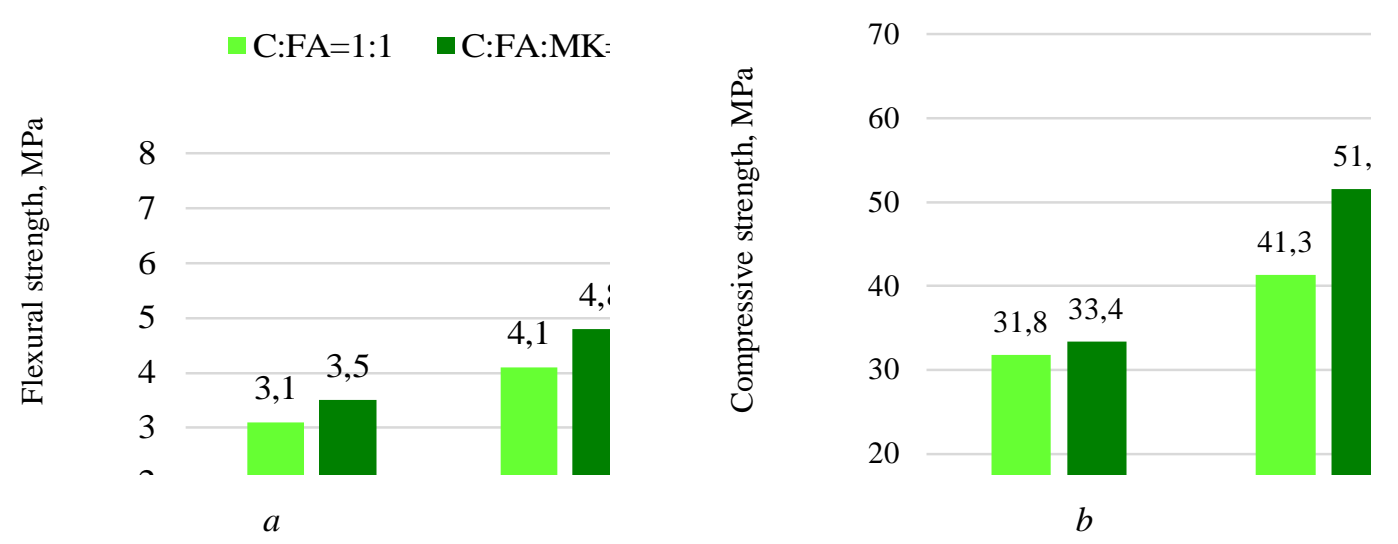

Fig. 3. Flexural (a) and compressive (b) strength of composites with replacement fly ash by $10 \%$ metakaolin

The crack resistance coefficient (ratio of flexural strength to compressive strength) of cementing system increases after 28 days, when amount of fly ash increases in ratio cement: fly ash from 1:0 to 1:2. Cementing system with ratio cement:fly ash 1:2 may be regarded as lower brittle since the crack resistance coefficient is 0.155 .

Fly ash was replaced by metakaolin in amount of $10 \mathrm{wt}$. \% to increase the physical and mechanical properties of the ECC matrix. According to the test results, the flexural strength after 28 days (Fig. 3, $a$ ) of composite with metakaolin is higher in $10 \%$ and reaches $6.7 \mathrm{MPa}$. However, the compressive strength of composites with metakaolin enchases significantly (Fig. 3,b). Thus, compressive strength of composite with metakaolin after 28 days increases in $15.8 \%$.

Alkaline activator $\left(\mathrm{Na}_{2} \mathrm{SO}_{4}\right)$ was introduced to the mix in amount of 2.0-6.0 wt. \%. to accelerate gain of early strength (Fig. 4).

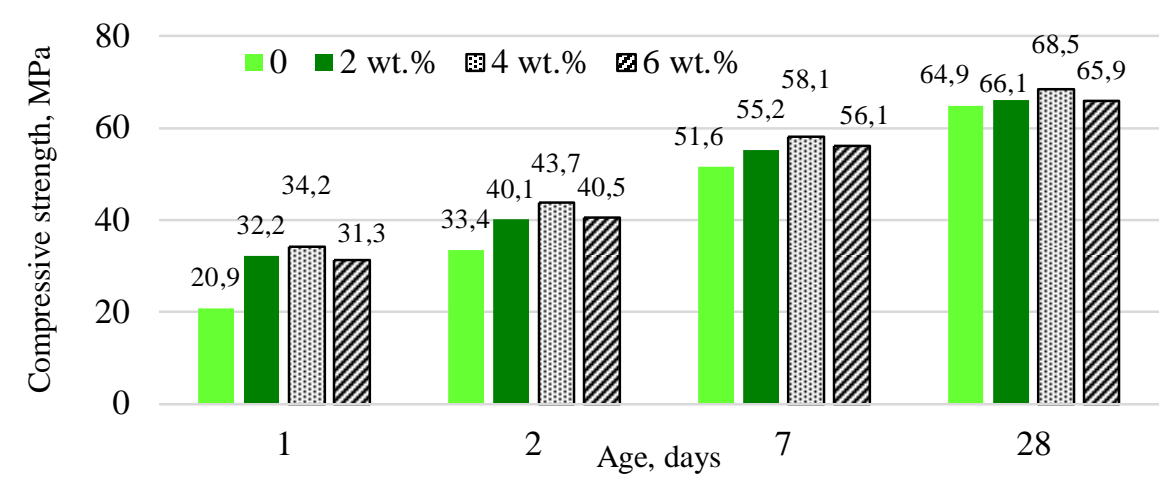

Fig. 4. Compressive strength of composites with alkaline activation

The addition of sodium sulfate allows to provide increasing of early strength of composites. Thus, the strength of the modified composite increases in 1.5 times and reaches values of $32.2 \mathrm{MPa}$ after 1 day, 
when 2.0 wt. $\% \mathrm{Na}_{2} \mathrm{SO}_{4}$ was introduced. Alkaline activated composites characterized increasing of compressive strength after 28 days to $66.1-68.5 \mathrm{MPa}$ and rapid strength development Rc2/Rc28 $=0.61$. The using sodium sulfate in amount $6 \mathrm{wt}$. \% causes decreasing of strength development.

Reaction between $\mathrm{Ca}(\mathrm{OH})_{2}$ and $\mathrm{Na}_{2} \mathrm{SO}_{4}$ in the presence of high-aluminate metakaolin or fly ash occurs with the formation of $\mathrm{CaSO}_{4} \cdot 2 \mathrm{H}_{2} \mathrm{O}$ and $\mathrm{NaOH}$ due to the formation of ettringite. The higher content of $\mathrm{Al}_{2} \mathrm{O}_{3}$ in metakaolin and its higher dispersion in comparison with fly ash provides acceleration this reaction, which causes increasing of alkalinity of the liquid phase of cement paste (Marushchak, 2016). The cations of sodium contributes to hydrolysis of the alite phase of the Portland cement clinker. The reactions connected with pozzolanic activity of the ultrafine additives are accelerated and new fibrous formations from the CSH-phases take place in unclinker part of cement matrix.

\section{Conclusions}

1. Composition of cementing matrix of ECC was designed by the method of mathematical experiment planning according to strength criteria. Based on graphical interpretation of mathematical models, it was established that the most effective ratio cement:fly ash was 1:1 with content of PCE 0.75 wt. $\%$.

2. The combination of fly ash and metakaolin provide enhance the compressive and flexural strength of cementing matrix at the early and later age. Partial replacement of fly ash by metakaolin with higher surface activity leads to increased flexural strength due to the rapid formation of fibrous habitus hydration products in unclinker part that reinforce the matrix on the microlevel.

3. Alkaline activation of cement system provides increasing of early strength after 1 day in 1.5 time, obtaining strength after 28 days of 66.1-68.5 MPa and rapid strength development (Rc2/Rc28 = 0.61), that creating of possibility decreasing consumption of Portland cement and design more suitable mix proportion to satisfy the demand of civil engineering and reduce the environmental impact.

\section{References}

Sanytsky, M., Marushchak, U., Olevych, Y., Novytskyi, Y. (2020). Nano-modified ultra-rapid hardening Portland cement compositions for high strength concretes. Lecture Notes in Civil Engineering 47, $392-399$. DOI:10.1007/978-3-030-27011-7_50.

Torres, A., Burkhart, A. (2016). Developing sustainable high strength concrete mixtures using local materials and recycled concrete. Materials Sciences and Applications 7, 128-137. DOI:10.4236/msa.2016.72013.

Li, V. C. (2003). On Engineered Cementitious Composites (ECC).A review of the material and its applications. Journal of Advanced Concrete Technology 1/3, 215-230. DOI.10.3151/jact.1.215.

Marcalikova Z., Cajka R., Bilek V., Bujdos D., Sucharda O. (2020). Determination of mechanical characteristics for fiber-reinforced concrete with straight and hooked fibers. Crystals 10, 545. DOI:10.3390/cryst10060545

Gholizadeh H., Dilmaghan S. (2018). The study of mechanical properties of high strength concrete containing steel and polypropylene fibers. Civil Engineering Journal 4/1, 221-230. DOI: 10.28991/cej-030981.

Chethan, V. R., Ramegowda, M., Manohara, H. E. (2015). Engineered Cementitious Composites - A review. International Research Journal of Engineering and Technology 2/5, 144-149. DOI.10.28991/cej-03091112.

Yu, K., Jiangtao, Y., Dai J.-G. (2018). Development of ultra-high performance engineered cementitious composites using polyethylene (PE) fibers. Construction and Building Materials 158, 217-227. DOI.10.1016/ J.CONBUILDMAT.2017.10.040

Mangulkar, M., Jamkar, S. (2013). Review of particle packing theories used for concrete mix proportioning. International Journal of Scientific \& Engineering Research 4/5, 143-148. https://www.researchgate.net/ publication/309900695_Review_of_Particle_Packing_Theories_Used_For_Concrete_Mix_Proportioning

Zhang J., Gong Ch., Guo Z., Zhang M. (2009). Engineered cementitious composite with characteristic of low drying shrinkage. Cement and Concrete Research 39, 303-312. DOI:10.1016/j.cemconres.2008.11.012.

Sanytsky, M., Kropyvnytska, T., Fic, S., Ivashchyshyn, H (2020). Sustainable low-carbon binders and concretes. E3S Web of Conferences 166, 06007. DOI:10.1051/e3sconf/202016606007.

Sobol, K., Blikharskyy, Z., Petrovska, N., Terlyha, V. (2014). Analysis of structure formation peculiarities during hydration of oil-well cement with zeolitic tuff and metakaolin additives. Chemistry and Chemical 8/4, 461465. DOI : https://doi.org/10.23939/chcht08.04.461 


\title{
Designing of alkaline activated cementing matrix of Engineered Cementitious Composites
}

Borziak, O. S., Plugin, A. A., Chepurna, S. M., Zavalniy, O. V., Dudin, O. A. (2019). The effect of added finely dispersed calcite on the corrosion resistance of cement compositions. IOP Conf. Series: Materials Science and Engineering 708, 012080. DOI:10.1088/1757-899X/708/1/012080.

Marushchak, U., Sanytsky, M., Sydor, N., Braichenko, S. (2018). Research of nanomodified engineered cementitious composites. Proceedings of the 2018 IEEE 8th International Conference on Nanomaterials: Applications and Properties 8914835. DOI:10.1109/NAP.2018.8914835

Krivenko, P., Sanytsky, M., Kropyvnytska, T. (2018). Alkali-sulfate activated blended portland cements. Solid State Phenomena 276, 9-14. DOI:10.4028/www.scientific.net/SSP.276.9

Tolmachov, S., Belichenko, O., Zakharov, D. (2017). Influence of additives on flexural strength of concrete. MATEC Web of Conferences 116, 01019. DOI:10.1051/matecconf/201711601019.

Plank, J., Sakai, E., Miao, C. W., Yu, C., Hong, J. X. (2015). Chemical admixtures - Chemistry, applications and their impact on concrete microstructure and durability. Cement and Concrete Research 78/A, 81-99. DOI: https://doi.org/10.1016/j.cemconres.2015.05.016

Sydor, N., Marushchak, U., Braichenko, S., Rusyn, B. (2021). Development of Component Composition of Engineered Cementitious Composites. Lecture Notes in Civil Engineering 100, 459-465. DOI: 10.1007/978-3-03057340-9_56

Marushchak U., Sanytsky M., Mazurak T., Olevych Y. (2016). Research of nanomodified portland cement compositions with high early age strength. Eastern-European Journal of Enterprise Technologies 6/6, 50-57. DOI: https://doi.org/10.15587/1729-4061.2016.84175

У. Д. Марущак, М. А. Саницький, Н. І. Сидор, І. В. Маргаль Національний університет “Львівська політехніка", кафедра будівельного виробництва

\section{РОЗРОБЛЕННЯ ЛУЖНО-АКТИВОВАНОЇ ЦЕМЕНТНОЇ МАТРИЦІ ІНЖЕНЕРНИХ ЦЕМЕНТУЮЧИХ КОМПОЗИТІВ}

\author{
() Марущак У. Д., Саницький М. А., Сидор Н. І., Маргаль I. В., 2021
}

Актуальною проблемою сучасного будівництва є розроблення високофункціональних матеріалів, які характеризуються високою міцністю на стиск та згин, довговічністю, експлуатаційними властивостями для забезпечення стійкості конструкцій. Одним з таких матеріалів $є$ інженерні цементувальні композити (ЕСС) - особливий клас високофункціональних дисперсно-армованих цементних матеріалів. ЕСС характеризуються утворенням множинних тріщин за навантаження і деформаційних зміцнень під час розтягування. Для забезпечення підвищених властивостей матриця інженерних цементувальних композитів повинна бути запроектована з урахуванням принципів мікромеханіки, що передбачають оптимізацію компонентного складу та мікроструктури матеріалу з урахуванням взаємодії цементної матриці та волокон. Властивостей високоміцної цементної матриці досягають через отримання щільної упаковки частинок. Підвищення експлуатаційних властивостей ЕСС досягається частковою заміною цементу додатковими цементувальними матеріалами, зокрема золою-винесення. Дібрано співвідношення компонентів в'язкого і заповнювача та витрати суперпластифікатора методом ортогонально-центрального композиційного планування. Оптимальне відношення компонентів цемент: зола винесення: пісок становить 1:1:1, а витрата полікарбоксилатного суперпластифікатора $0,75 \%$ від маси в'язкого. Зниження негативного впливу підвищеної кількості золи-винесення забезпечується введенням метакаоліну та лужного активатора тверднення. Це забезпечує підвищення міцності цементної системи через 1 добу в 1,5 раза, отримання показників ії міцності через 28 діб 66,1 МПа та питомої міцності $\mathrm{R}_{\mathrm{c} 2} / \mathrm{R}_{\mathrm{c} 28}=0,61$, що створює можливість ефективного використання портландцементу, зменшення його витрати та зниження негативного впливу на навколишнє середовище.

Ключові слова: інженерний цементувальний композит, лужна активація, зола-винесення, метакаолін, полікарбоксилатний суперпластифікатор, міцність. 